\title{
META ANALYSIS THE EFFECT OF HEALTH BELIEF MODEL ON IMPLEMENTATION OF BREAST SELF-EXAMINATION IN WOMEN
}

\author{
Fauzia Ichlasul Sekar'), Hanung Prasetya'), Bhisma Murti1) \\ ${ }^{1)}$ Masters Program in Public Health, Universitas Sebelas Maret \\ ${ }^{2}$ Health Polytechnics, Ministry of Health Surakarta
}

\begin{abstract}
Background: The health belief model (HBM) is frequently utilized examine the beliefs about breast cancer screening behavior using breast self-examination. The dimensions included are perceived susceptibility, seriousness, benefit, barrier, cues for action, selfefficacy, and health motivation. A systematic review and a meta-analysis were performed to determine the effect of health belief model on implementation of breast selfexamination in women

Subjects and Method: Literature search was performed using PubMed, Google Scholar, Springer Link, and Scopus databases. The study population was adult women. Intervention was high perceived benefit with comparation was low perceived benefit. The study outcome was breast self-examination. Keywords used "health belief model" OR "health belief" OR "belief" AND "breast self-examination" OR "breast cancer screening". Pooled adjusted odds ratios were calculated using Revman 5.3.

Results: A meta analysis using 5 primary studies from Turkey, Ethiopia, and Indonesia reported that perceived benefit had weak effect on the implementation of breast selfexamination in women $(\mathrm{aOR}=1.07 ; 95 \% \mathrm{CI}=0.94$ to $1.20 ; \mathrm{p}=0.300)$.

Conclusion: Perceived benefit has weak effect on the implementation of breast selfexamination in women.

Keywords: breast cancer, breast self-examination, health belief model, perceived benefit

\section{Correspondence:}

Fauzia Ichlasul Sekar. Masters Program in Public Health, Universitas Sebelas Maret. Jl. Ir. Sutami 36A, Surakarta 57126, Central Java. Email: fauziasekar10@gmail.com. Mobile: 082324756260.
\end{abstract}

